Developments in American Politics 2 
Also available from Macmillan

Patrick Dunleavy, Andrew Gamble, Ian Holliday and Gillian Peele (eds)

DEVELOPMENTS IN BRITISH POLITICS 4

Peter A. Hall, Jack Hayward and Howard Machin (eds) DEVELOPMENTS IN FRENCH POLITICS (Revised Edition)

Gordon Smith, William E. Paterson, Peter H. Merk1 and Stephen Padgett (eds) DEVELOPMENTS IN GERMAN POLITICS

Stephen White, Judy Batt and Paul G. Lewis (eds) DEVELOPMENTS IN EAST EUROPEAN POLITICS

Stephen White, Alex Pravda and Zvi Gitelman (eds) DEVELOPMENTS IN RUSSIAN AND POST-SOVIET POLITICS (Third Edition)

Forthcoming

Patrick Dunleavy ANALYSING BRITISH POLITICS 


\section{Developments in American Politics 2}

Gillian Peele

Christopher J. Bailey

Bruce Cain

B. Guy Peters

Editors

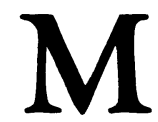

MACMILLAN 
Editorial matter and selection (C) Gillian Peele, Christopher J. Bailey, Bruce Cain, B. Guy Peters 1994

Individual chapters (in order) (C) Pippa Norris, Bruce Cain, Paul S. Herrnson, Frank L. Davis, John Hart, Roger H. Davidson, Gillian Peele, Martin Laffin, John Kincaid, Desmond S. King, Paul Peretz, B. Guy Peters, John Francis, Phil Williams, Calum Paton, Barbara Burrell, Tim Hames, Christopher J. Bailey 1994

All rights reserved. No reproduction, copy or transmission of this publication may be made without written permission.

No paragraph of this publication may be reproduced, copied or transmitted save with written permission or in accordance with the provisions of the Copyright, Designs and Patents Act 1988, or under the terms of any licence permitting limited copying issued by the Copyright Licensing Agency, 90 Tottenham Court Road, London W1P 9HE.

Any person who does any unauthorised act in relation to this publication may be liable to criminal prosecution and civil claims for damages.

First published as Developments in American Politics, 1992

Reprinted 1992, 1993

Second edition 1994

Published by

THE MACMILLAN PRESS LTD

Houndmills, Basingstoke, Hampshire RG21 2XS

and London

Companies and representatives

throughout the world

ISBN 978-0-333-59653-1

ISBN 978-1-349-23497-4 (eBook)

DOI 10.1007/978-1-349-23497-4

A catalogue record for this book is available from the British Library.

Copy-edited and typeset by Povey-Edmondson

Okehampton and Rochdale, England 


\section{Contents}

Preface $\quad$ xi

List of Contributors xiii

List of Tables and Figures $\quad$ xv

List of Abbreviations xvi

Map of the United States of America xviii

1 Introduction Gillian Peele, Christopher J. Bailey, B. Guy Peters and Bruce Cain 1

\section{PART ONE: DYNAMICS}

2 The 1992 Presidential Election, Voting Behavior and Legitimacy Pippa Norris

The Social and Geographic Basis of the Vote 20

Changes in the geographic basis of the vote 24

Changes in the social basis of the vote 26

Evaluations of the Bush Presidency 30

Perot and the Challenge to Two-party Politics 36

Conclusions $\quad 41$

3 Racial and Ethnic Politics Bruce Cain 45

The Spread of Multiculturalism 49

Political Diversity and Multiracialism 53

The Political Consequences of Multiracialism $\quad 60$

4 American Political Parties: Growth and Change Paul S. Herrnson $\quad 67$

Emergence and Decline $\quad 68$

Party Reform and Renewal 71

Party Organizations and Campaign Activities $\quad 75$

$\begin{array}{ll}\text { Conclusion } & 82\end{array}$

5 Interest Groups and Policymaking Frank L. Davis 85

Interest Groups' Narrower Focus $\quad 86$ 
Variation in Involvement $\quad 90$

Private Versus Public Interest Groups 91

Representativeness of Interest Groups 92

Bias? $\quad 93$

How Involved in Health Care are Interest Groups? 94

Subsystems Versus Issue Networks 94

Resources, Tactics, and 'Interested Publics' 97

Interest group tactics $\quad 98$

Lobbying $\quad 98$

Advertisements aimed at government officials $\quad 98$

Campaign contributions $\quad 99$

Appealing to the courts $\quad 100$

Publicizing public support 101

News coverage and mass advertising 101

Tactics in the Health Care Debate 102

A Coordinated Campaign 105

Legitimation of Policy 106

Final Conclusions 107

\section{PART TWO: THE INSTITUTIONAL FRAMEWORK}

6 The Presidency in the 1990s John Hart 110

The Clinton Inheritance 112

The Context of the Clinton Presidency 118

The election and the mandate 118

The policy agenda $\quad 120$

Leadership style $\quad 121$

The Clinton Presidency: Problems and Prospects 123

Managing Congress 125

Managing the media $\quad 127$

Managing public opinion $\quad 128$

Institutional support $\quad 130$

The Post-Watergate Presidency and Presidential

Leadership 131

7 Congress in Crisis ... Once Again Roger H. Davidson 134 Sources of Crisis 135

Congress as Representative: Parochialism and

$\begin{array}{ll}\text { Professionalism } & 137\end{array}$

$\begin{array}{ll}\text { Constituency outreach } & 138\end{array}$ 
The 'Incumbency Party' 139

Congress as Lawmaker: Organizational Fissures $\quad 141$

The Committee system 141

Leadership and management 145

Paths to the Present Crisis 147

Conclusion: The Two Congresses Problem 150

8 The Supreme Court and the Constitution Gillian Peele 152

The Clinton Administration and the Department of Justice 156

The Composition of the Supreme Court 160

The Judicial Role 163

The Conservative Legacy $\quad 165$

Abortion $\quad 169$

Church and State $\quad 169$

$\begin{array}{ll}\text { Conclusion } & 170\end{array}$

9 Reinventing the Federal Government Martin Laffin 172

The Challenges of the 1990s 173

The Role of the Federal Government 175

The Structure of the Federal Government 176

Presidential Leadership of the Federal Government 179

Congress and the Bureaucracy 182

Inspectors General 185

The Management of Federal Departments 186

Bureaucrats as 'Political Entrepreneurs' 188

The Role of Political Appointees 189

Appointee-Careerist Relations 191

The 'Quiet Crisis' and Reinvigorating the Bureaucracy 192

The National Performance Review 193

Third Party Government 196

The Prospects for Change 198

10 Governing the American States John Kincaid 200

Explaining the Paradox 201

Origins of American Federalism 203

Dual, Cooperative, and Coercive Federalism 205

Characteristics of Coercive Federalism 208

Diminished federal aid to states and localities $\quad 208$

Aid to persons over places 209 
Conditions of aid to states and localities $\quad 210$ Federal mandates on states and localities 211

Federal preemption of state and local authority 212 Intergovernmental tax immunities 213

Decline of cooperative programs 213

Federal court orders $\quad 214$

Conclusion

\section{PART THREE: PUBLIC POLICY}

11 The Politics of Urban Policy Desmond S. King 220

The Problems of Cities $\quad 220$

The Politics of the Cities 224

Federal Policy and the Cities 229

Conclusion 233

12 Economic Policy Paul Peretz 237

Introduction $\quad 237$

The 1980-86 Period 238

The Post-1986 Period 239

Fiscal policy under Bush 241

Monetary policy under Bush 244

Fiscal policy under Clinton 246

Monetary policy under Clinton 249

International trade $\quad 250$

Policy Outcomes 251

13 Social Policy B. Guy Peters 253

The United States as a Welfare State Laggard 253

The Fundamental Problem: Inequality 257

The politics of poverty 259

The 'New Poverty' 264

Reagan, Bush, and the loosening of the social safety net $\quad 267$

The Challenges for President Clinton 268

Fiscal Restraints - the Mortmain of Reagan and Bush 269

14 Environmental Policy John Francis 271

The Character of American Environmental Politics 272 
The Expanding Range and Persisting Nature of

Environmental Policies

The Institutional Context

Political Parties, Interest Groups, and Environmental Politics

The Western Landscape and the Reccurring Question of Federal Land Use

Logging

Toxic substances

Transnational Dimensions

Conclusion

15 Foreign Policy Phil Williams

Introduction

The End of the Cold War

New Challenges and Issues

The Domestic Context

Implications for Policy

\section{PART FOUR: CONTEMPORARY ISSUES}

16 Health Policy: The Analytics and Politics of Attempted

Reform Calum Paton

The Legacy

The Reemergence of Regulation

The Main Proposal

The Political Environment

Toward the Clintons' Plan

The 'Oregon Plan'

Conclusion

17 Women in American Politics Barbara Burrell 325

The Range of Women's Organizations 326

Open Seats $\quad 329$

General Elections $\quad 330$

Policy Representation for Women 331

18 The Changing Media Tim Hames 335

The New American Media 335

The Press Post-mortem on $1988 \quad 338$ 
The Candidates' New Media Strategies $\quad 340$

The Media's Strategy to the Candidates 342

President Clinton's Media Strategy 344

Conclusion 346

PART FIVE: THEORETICAL PERSPECTIVES

19 Visions of American Politics Christopher J. Bailey 350

The Study of American Politics 351

The institutional approach $\quad 353$

The behavioral approach $\quad 356$

The rational choice approach 358

Visions of American Politics 361

Interest Groups $\quad 364$

Voting 365

The presidency 366

The US Congress $\quad 367$

The Supreme Court $\quad 369$

Bureaucracy $\quad 370$

The policy process 371

The Study of Politics in the Post-Cold War Era 373

Guide to Further Reading $\quad 374$

Bibliography $\quad 379$

Index $\quad 407$ 


\section{Preface}

This is the second Developments in American Politics volume. All the chapters are new and, with the exception of the editors and Desmond King, there is a new group of contributors. We have been fortunate in attracting a truly international team of prominent scholars from the United States, Australia, and Great Britain. The editorial team has been greatly strengthened by the addition of Professor B. Guy Peters who has brought his wide range of contacts and scholarly expertise to bear on this project.

As in the last volume, individual authors were asked both to analyze recent developments in American politics, and to review some of the crucial theories and models available for interpreting them. All authors were asked to concentrate on the contemporary American scene, and especially on the impact of the Clinton administration on the politics and policies of the United States.

Writing about the United States using an international team of authors presents certain stylistic problems. As in the previous volume, the editors have decided that spelling should be Americanized throughout to promote consistency. On the other hand, some specifically American usages have been excised. Where appropriate, the party and state of members of Congress have been included. The references to works cited in the chapters are collected together at the end of the book. There is also a short guide to further reading for each of the chapters (on p. 374).

The editors would like to thank our publisher Steven Kennedy for the help and encouragement he has given to this volume. We would also like to thank our anonymous referees and especially Steve Reilly, who read the entire manuscript of this book and its predecessor.

The editors acknowledge with gratitude the intellectual support given by their colleagues at the University of Oxford, Keele University, the University of California at Berkeley, and the University of Pittsburgh. Chris Bailey would specifically like to thank Dick Engstrom, Peter John, Mike Tappin, Jonathan Knuckey, and Ian Scott for listening, reading, and criticizing. 
Others whom the editors and the contributors would like to thank are Mick Moran, Nigel Stanier, Cornell Clayton and Brian Hatch.

The production of this book would have been impossible without the assistance of the highly professional administrative and secretarial staff in our various academic institutions. A particular word of thanks is due to Pauline Shepheard, the College Secretary at Lady Margaret Hall, and to Susan Waters, the Tutors' Secretary. Their calm efficiency and helpfulness have been invaluable in the various stages of the book's life. The editorial team is also grateful to Wiltrandt Grashoff at the University of Pittsburg and to the staff of the Institute of Governmental Studies at Berkeley for all their help and hospitality.

On a personal level, the British editors realize how much they owe to the hospitality of American colleagues and friends. We should particularly like to mention Paul Herrnson, Cathy Helms, Maggie Fish, Laura Doan, Marlene Mussell, Chris Hall, Jackie Wardell, John and Leslie Francis, Colin Campbell, Jim Thurber, and John and Marjorie O'Shaugnessy and Steve and Cindy Saboe.

Finally, we should like to thank our contributors, whose patience and prompt responses to queries have helped to get this book to the finishing line roughly on time.

Gillian Peele Christopher Bailey Bruce Cain

B. Guy Peters 


\section{List of Contributors}

Christopher J. Bailey is Senior Lecturer in American Studies at Keele University.

Barbara Burrell is a researcher at the Wisconsin Survey Research Laboratory at the University of Wisconsin Extension.

Bruce Cain is Professor of Government at the University of California, Berkeley, where he is also Associate Director of the Institute of Government Studies, Berkeley.

Roger H. Davidson is Professor of Government at the University of Maryland, College Park.

Frank L. Davis is Associate Professor of Government at Lehigh University.

John Francis is Professor of Politics at the University of Utah.

Tim Hames is American Studies Research Officer at Nuffield College, Oxford.

John Hart is Reader in Political Science at the Australian National University.

Paul Herrnson is Associate Professor of Government at the University of Maryland, College Park.

John Kincaid is Executive Director of A.C.I.R.

Desmond S. King is Fellow and Tutor in Politics at St John's College, Oxford.

Martin Laffin is Senior Lecturer in Public Policy at the Graduate School of Business, University of Sydney, and was Visiting Fellow in the Graduate Public Policy Program, Georgetown University, Washington D.C., 1992-93.

Pippa Norris is Associate Director and Lecturer, Joan Shorenstein Barone Center on Press, Politics and Public Policy at Harvard University.

Calum Paton is Professor of Health Care Management at Keele University.

Gillian Peele is Fellow and Tutor in Politics at Lady Margaret Hall, Oxford.

Paul Peretz is Associate Professor of Political Science at California State University, Fullerton. 
B. Guy Peters is Maurice Falk Professor of American Government at the University of Pittsburgh.

Phil Williams is Professor of Public and International Affairs and Director of the Ridgeway Center, University of Pittsburgh. 


\section{List of Tables and Figures}

Tables

2.1 Presidential elections 1968-92 21

2.2 Structural change in the size of voting groups 23

2.3 Social basis of the Democratic vote, 1952-92 29

2.4 Changes in the Presidential vote, 1988-92 30

2.5 Approval of President Bush 33

2.6 Economic evaluations and voting choice 34

2.7 Model of voting choice 35

2.8 Timing of voting decision 35

2.9 Change in the vote, 1988-92 40

2.10 Trust and cynicism in government, $1992 \quad 42$

3.1
Distribution of states by percent minority
populations

3.2 Distribution of Congressional districts by minority

3.3 Party identification and ideology 65

5.1 Examples of interest groups involved in health policy 88

5.2 Examples of the campaign expenditures of healthrelated Political Action Committees for the 1991-2 election cycle 104

13.1 Major welfare state beneficiaries and expenditures, $1990 \quad 256$

13.2 Poverty and program participation by race 260

\section{Figures}

2.1 Electoral college 1992 U.S. election 25

4.1 Party receipts, 1976-92 76

12.1 Unemployment and real per capita disposable income, 1987-93 


\section{List of Abbreviations}

A.A.R.P. American Association of Retired Persons

A.B.C. American Broadcasting Corporation

A.C.I.R. Advisory Commission on Intergovernmental

Relations

A.F.D.C. Aid to Families with Dependent Children

A.F.L.-C.I.O. American Federation of Labor-Congress of

Industrial Organizations

A.H.P. Accountable Health Partnership

A.M.A. American Medical Association

A.P.A.

Administrative Procedures Act

Ark.

Arkansas

bn.

Billion

C.B.S. Columbia Broadcasting System

C.D.B.G. Community Development Block Grant

C.E.T.A. Comprehensive Employment and Training Act

D. Democrat

D.C. District of Columbia

D.C.C.C. Democratic Congressional Campaign Committee

D.N.C. Democratic National Committee

D.S.C.C. Democratic Senatorial Campaign Committee

D.O.D. Department of Defense

D.O.J. Department of Justice

D.R.G.s Diagnostic Related Groups

E.E.A. Economic Equity Act

E.I.S. Environmental Impact Statement

EMILY Early Money Increases Like Yeast

E.P.A. Environmental Protection Agency

E.R.A. Equal Rights Amendment

F.B.I. Federal Bureau of Investigation

F.D.A. Food and Drug Administration

F.D.R. Franklin Delano Roosevelt

F.E.C.A. Federal Election Campaign Act

F.Y.

Fiscal Year

G.A.O. General Accounting Office 
G.O.P.

G.R.S.

G.S.

H.I.A.A.

H.I.P.C.

H.M.O.s

H.U.D.

I.G.

Ill.

I.N.S.

L.A.

Miss.

M.T.V.

N.A.F.T.A

N.A.S.A.

N.B.C.

N.C.P.S.

N.E.P.A.

N.E.S.

N.I.H.

N.O.W.

N.W.P.C.

O.E.C.D.

P.A.C.

P.A.S.

P.P.I.

P.R.

R.

R.N.C.

S.E.S.

S.M.S.P.

T.C.O.s

T.Q.M.

U.D.A.G.
Grand Old Party (Republican Party)

General Revenue Sharing

General Schedule

Health Insurance Association of America

Health Insurance Purchasing Cooperative

Health Maintenace Organizations

Housing and Urban Development

Inspector General

Illinois

Immigration and Naturalization Service

Los Angeles

Mississippi

Multiple Transferable Vote

North American Free Trade Agreement

National American Space Agency

National Broadcasting Corporation

National Commission on the Public Service

National Environmental Policy Act

National Election Survey

National Institutes of Health

National Organization of Women

National Women's Political Caucus

Organization for Economic Cooperation and

Development

Political Action Committee

Presidential Appointment [with] Senate

Confirmation

Progressive Policy Institute

Proportional Representation

Republican

Republican National Committee

Senior Executive Service

Single Member Simple Plurality (First Past the Post)

Transnational Criminal Organizations

Total Quality Management

Urban Development Action Grant 
The United States of America: states and main cities 
(excluding Alaska and Hawaii)

xix 